軽微な肉眼所見で広範な浸潤を呈した胃悪性リンパ腫の 1 例

\begin{tabular}{|c|c|c|c|c|}
\hline & & 分医科大 & 学第 1 外 & \\
\hline 掛谷 & 和俊 & 木下 & 忠彦 & 桑原 \\
\hline 斉藤 & 貴生 & 小林 & 迪夫 & \\
\hline
\end{tabular}

\title{
A CASE REPORT OF MALIGNANT LYMPHOMA OF THE STOMACH SHOWING EXTENSIVE INVASION AND MINIMAL MACROSCOPIC FINDINGS
}

\section{Kazutoshi KAKETANI, Tadahiko KINOSHITA, Akihiko KUWAHARA, Takao SAITO and Michio KOBAYASHI}

First Department of Surgery, Medical College of Oita

象引用語：胃悪性リンパ畽, 免疫グロブリン染色

I.はじめに

胃悪性リンパ腫のらち表層払大型を呈するものは, 予後がよいとされている(1) 3). 今回, 著者らは臨床的に 非常に軽微な IIc 様病変を呈したにもかかわらず，著 しい漫潤とリンパ節転移があり, 術後半年で死亡した 症例を释験したので若干の文献的考察を加えて報告す る.

\section{II. 症 例}

患者：60歳，女性.

主訴：上腹部不快感。

既往歴：特記すべきことなし。

家族歴：特記すべきことなし，

現病歴：昭和 61 年 7 月上旬より空腹時に上腹部不快 感が出現し，7月26日, 近医にて胃内視鏡を施行され, 慢性胃炎の診断のもとに内服治療を受けていた。しか し，軽快しないため 9 月 3 日再度，胃内視鏡を施行さ れた。生検の結果, 胃悪性リンパ腫と診断されたため 9 月26日に当科入院となった。

入院時現症：身長 $153 \mathrm{~cm}$, 体重 $50.6 \mathrm{~kg}$, 表在リンパ 節腫大はなく，肝・脾腫も認めなかった。その他，理 学的に異常は認めなかった。

入院時検查成績: 末梢血は, WBC $4,460 / \mathrm{mm}^{3}$, RBC $403 \times 10^{4} / \mathrm{mm}^{3}, \mathrm{Hb} 11.9 \mathrm{~g} / \mathrm{dl}, \mathrm{Ht} 38.3 \%$, Platelet $23.5 \times 10^{4} / \mathrm{mm}^{3}$ と正常であり, 異型細胞の出 現も認めなかった。生化学的には総蛋白 $6.9 \mathrm{~g} / \mathrm{dl}$, 血浆 蛋白分画albumin $64.2 \%, \alpha_{1} 3.2 \%, \alpha_{2} 7.8 \%, \beta$

$<1988$ 年 3 月 9 日受理 >別刷請求先：掛谷 和俊 干879-56 大分県大分郡㣣間町医大ヶ丘 1-1506 大 分医科大学第 1 外科
$7.4 \%, \gamma 17.3 \%$, 総ビリルビン $0.6 \mathrm{mg} / \mathrm{dl}$, alkaline phosphatase $222 \mathrm{IU} / l, \mathrm{LDH} 450 \mathrm{IU} / l$, 総コレステ ロール204mg/dl, amylase $82 \mathrm{IU} / l$ であり軽度の LDH 上昇が認められた。免疫グロブリンは IgG $1,530 \mathrm{mg} /$ $\mathrm{dl}, \mathrm{IgA} 248 \mathrm{mg} / \mathrm{dl}, \mathrm{IgM} 89.6 \mathrm{mg} / \mathrm{dl}$ と正常範囲内で あった. 睡場マーカーも, AFP 5.15ng/dl, CEA 1.16 $\mathrm{ng} / \mathrm{ml}$ と異常なかった。また胸・腹部単純 X線, 腹 部 computed Tomography（CT)，ガリウムシンチ $\left({ }^{67} \mathrm{Ga}\right.$-citrate) などでも特記すべき所見は認めなかっ た.

胃 $\mathrm{X}$ 線検查所見：立位充盈像では大小弯ともに壁 硬化像は認めなかった。背臥位二重造影では, 胃体上 部之幽門前庭部に病変を認めた（図 1 )。胃体上部では 後壁やや大弯よりに多中心性の粘膜七ダの集中を認め たが先細りや肥大の所見はなく潰瘍洂痕と診断された (図 2 右，矢印），一方，幽門部に乱いては淡い不整形 のバリウム斑と，その周囲の胃小区の大小不同が認め られ, IIC 型早期胃癌, 悪性リンパ隀などが疑われた(図 2 左, 矢印).

胃内視鏡所見：胃粘膜は全体的にやや浮尰状で発赤 が散在していた，胃体上部後壁には粘膜ヒダの集中を 伴らが悪性所見を欠き治撚期の線状潰湟と診断された (図 3 右)。また幽門部には白苔を伴う大整形の陥凹性 病変を認め, IIc 型早期胃癌が疑われたが良性清瘍や悪 性リンパ腫との鑑別が問題となった（図 3 左）。

胃生検では, 粘膜固有層から粘膜笳板にかけてク口 マチンに富んだ核を持つリンパ球様細胞がびをん性に 浸潤しており，核に異型性を有し一様に增殖している ことなどから胃悪性リンパ腫の診断であった。以上よ 
図 1 胃 X 線二重造影像. 胃壁の伸展性は良好であ り，胃体上部と幽門前庭部に病変を認める。

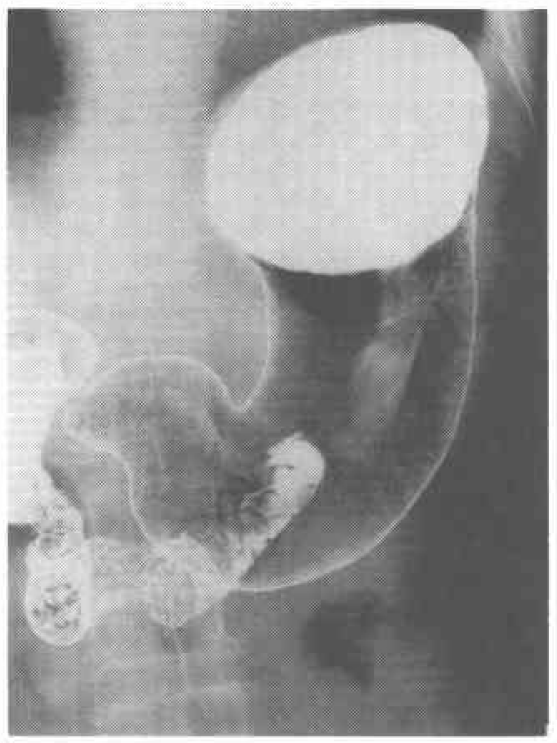

図 2 胃 X 線二重造影像。胃体上部に多中心性の粘膜 ヒダの集中（右図，矢印）と幽門部にバリウム斑と 胃小区の不整を認める (左図, 矢印)。
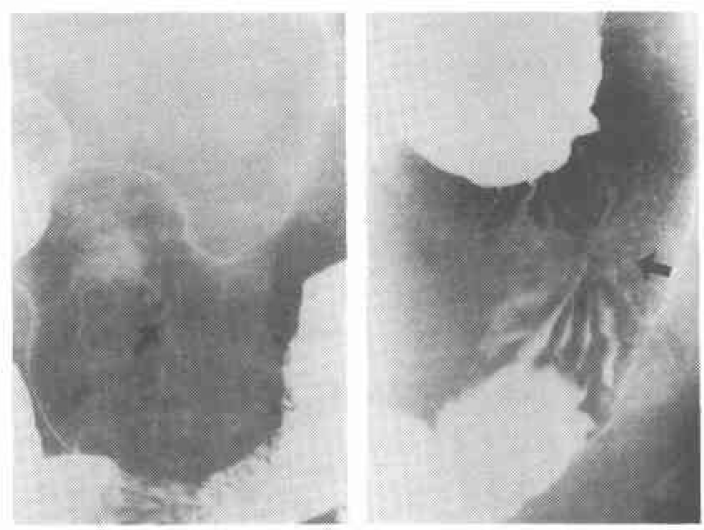

り早期胃悪性リンパ腫の診断のもとに, 昭和61年10月 7 日，胃全摘術を施行した。

手術所見：上腹部正中切開にて開腹した。開腹時, 少量の黄色透明な腹水が存在したが腹膜は平滑で播種 はなく肝・脾には特に異常を認めなかった。胃は䍝膜 平滑であり触診では胃内には明かな腫瘤は触れなかっ たが，胃周囲のリンパ節は，No. 1，3，4，5，7，8， 10 が大豆大から空至大に腫大しており硬結として触知 した. 胃全摘術, 脾・膵尾部合併切除と $\mathrm{R}_{3}$ のリンパ節
図 3 胃内視鏡所見。胃体上部後壁寄りに浅い線状潰 瘍之粘膜ヒダの集中を認め(右図, 矢印)，幽門部に は不整脈の浅い潰湯（左図，矢印）と周囲粘膜の軽 度発赤を認める。
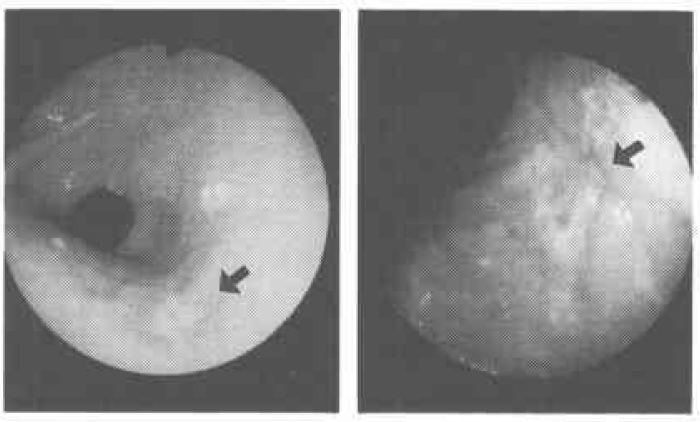

図 4 切除標本肉眼所見. 胃粘膜はやや浮腫で胃体上 部前後壁に潰痬と粘膜ヒダの集中(矢印)，幽門部に は浅い潰瘍 (矢頭印) を認める (上図). その病変構 築図では胃全体に腫瘍細胞が散見され，1 部では浆 膜下組織にも浸潤していた (下困).
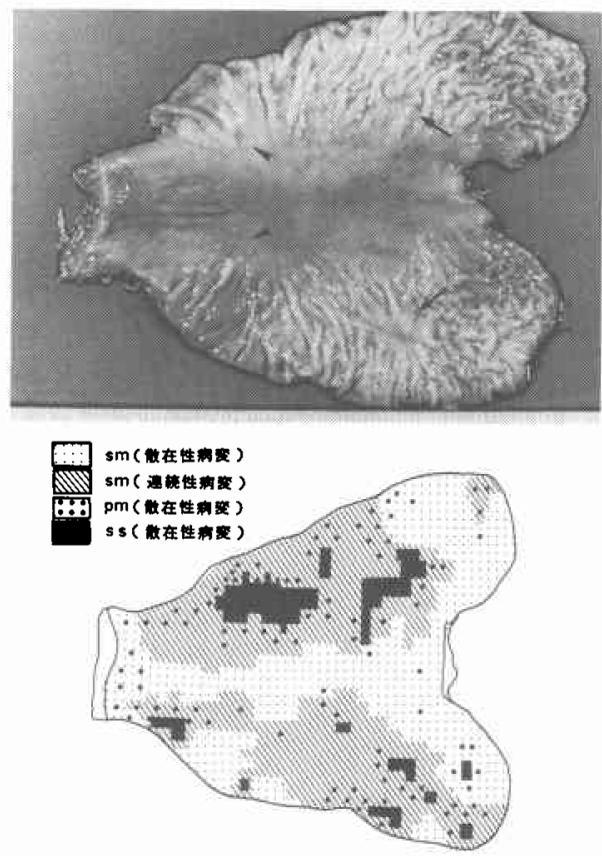

郭清を施行し, 再建は食道空腸 Roux-Y 吻合術を行っ た. 手術所見の要約は, 胃悪性リンパ腫, 表層型, $\mathrm{S}_{0}$, $\mathrm{P}_{0}, \mathrm{H}_{0}, \mathrm{~N}_{2}$, Stage III, $\mathrm{R}_{3}$, 絶対的治癒切除であっ た.

切除標本肉眼所見：胃粘膜は全体的にやや浮腫状 で，胃体上部前壁に粘膜ヒダの集中を伴う潰瘍疫痕と 
図 5 病理組的所学見，粘膜固有㬝にびまん性に腫 瘍細胞の浸潤を認め, 粘膜下層にも浸潤している(上 図). 筋層内にも巣状の漫灑が認められた (下図). $(\mathrm{HE} 40 \times)$

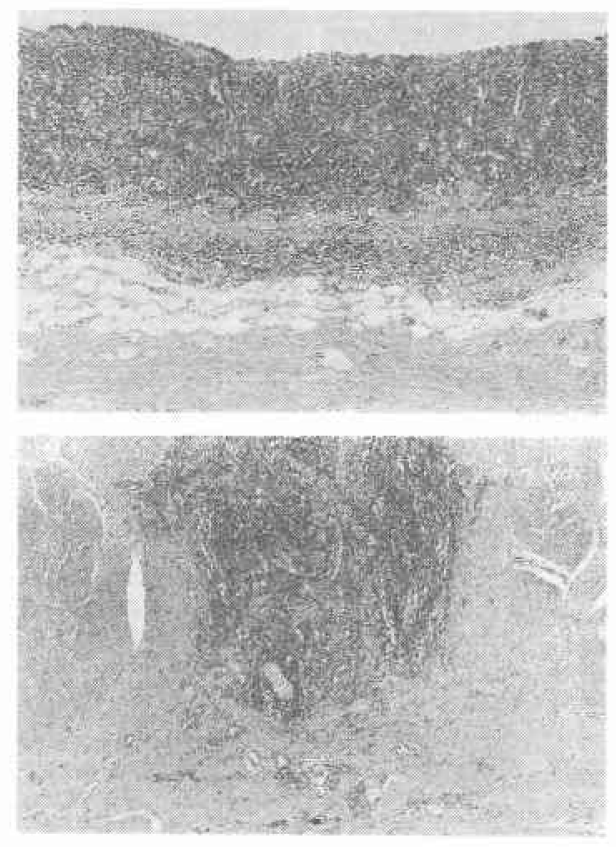

幽門前庭部後壁に浅いびらんを認めたが，明かな腫瘤 や巨大煼壁の形成など認めなかった(図 4 上)。その病 変構築図では, 胃体部大弯から前後壁を中心として sm での浸潤病巣が連続性に存在しており，その他 の部分にも切除断端付近を除いて広範に腫瘍細胞が散 在していた。さらに pm, ss む゙の浸潤病巣が散在性に 認められた（図４下）。

組織学的所見：粘膜固有層から一部は粘膜下層にか けて,びまん性に腫瘍細胞の浸潤が認められ(図 5 上), 固有筋層や浆膜下組織にも腫湯細胞の巣状漫潤が散見 された(図5下). 強払大では腫瘍細胞はクロマチンに 富み核の切れ込みなど異型性を示していたが，小型り ンパ球に酷似しているものも認められた(図6)。核に 切れ込みがあることより形態学的に B cell 由来であ ると診断された。また, peroxidase-antiperoxidase (PAP 法)にて免疫組織学的に IgG, M, A および $\lambda$-chain を染色すると, $\operatorname{IgG}, x-\lambda$-chain が一部のリ ンパ腫細胞に染色され多クローン性のパターンを示し た.しかしパラフィン切片であることより非特異的反 応の可能性も否定できなかった，以上より，LSG 分類 では非ホジキン, びまん型, B cell, 中細胞型で深達度
図 6 病理組織学的所見. 畽瘍細胞はクロマチンに富 み切り込みを有する核を持ち軽度の異型を呈してい る、枠内はPAP法に扔ける免疫グロブリン陽性細 胞を示している.（HE 400×）

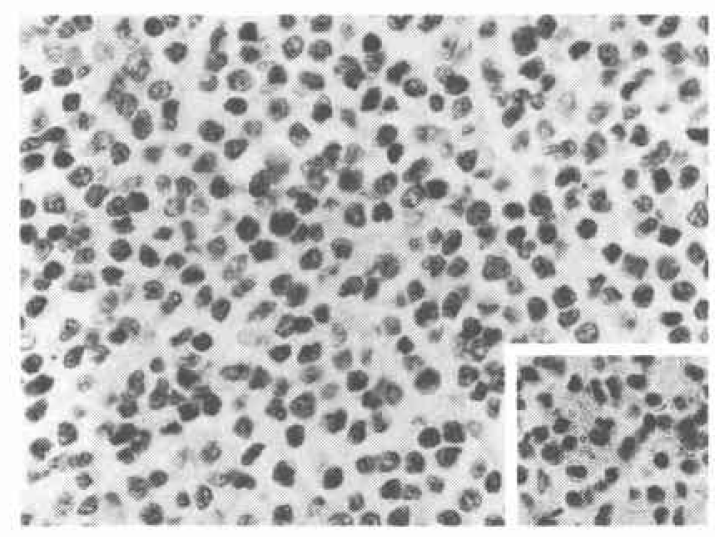

は SS と診断された。リンパ節転移はNo. 1，2，3，4， $5,6,7,8,10,11,12 ， 13$ すべてに認められた。な お術中，肉眼的には OW(一), AW(一)であったが 組織学的には口側断端の一部分に異型細胞の浸潤が認 められ ow (十)と診断された。しかし著しいリンパ節 転移があり，追加切除は無効と思われたため再手術は 行われず化学療法が施行された。

術後経過：術後 CHOP 療法 (cyclophosphamide $1,000 \mathrm{mg}$, adriamycin $60 \mathrm{mg}$, vincristine $3 \mathrm{mg}$, predonisone 30mg）を 1 回行った後，昭和61年11月27 日にいったん退院となった。外来にて CHOP 療法をさ らに 4 回行ったが，昭和62年 3 月下旬より全身リンパ 節腫大が出現し 5 月 9 日には肺炎を合併して死亡し た. 剖検所見では, 頸部・鼠径部などの表在リンパ節 のみでなく縦隔・大動脈周囲リンパ節など全身のリン パ節に転移がみられ小指等大から鵎卵大に累々之腫大 しており，また肝・膵・腎・腸間膜などにも多数の転 移巣が認められた。

\section{III. 考 察}

原発性胃悪性リンパ重は, 胃悪性腫瘍のうち0.5 $2.3 \%$ 占める比較的まれな疾患である1) 31. 性差はほ とんどないが若干男性に多く，年龄は40～60歳代に多 く約3/4がその年代に分布している12).

臨床的に胃悪性リンパ董は胃癌との鑑別が問題とさ れ, 種々の肉眼的分類がなされてきた ${ }^{1) 61}$. それらの分 類の中で本症例は, 佐野の表層型, 大井の浸潤型, 八 尾らの表層扗大型, 崎田らの表層びらん型などに近い 
と考えられるが，佐野の表層型のような IIC 型胃癌様 の形態はとらず表面の変化は軽微であり，また胃壁内 浸潤は著しかったが散在性の病変であり，巨大解壁や Borrmann 4 様の壁肥厚は認めず，どの型にも合致し ないように思われた。強いて分類するならば,川口ら5 の早期リンパ盾類似型とびまん浸潤型の性格をもら合 わせたタイプといえるが，その肉眼形態に合致しない 著しい散布・浸潤傾向は注目すべきことと思われる。

胃悪性リンパ稙の術前診断において，本症例のごと く軽微な粘膜所見しか呈さないようなるのでは, 慢性 胃炎, reactive lymphoid hyperplasia (RLH), IIc 型 胃癌などとの鑑別が問題となり，生検による確診率も $31.2 \sim 64 \%$ と低く7), 診断の困難さがうかがわれる.表 層拡大型胃悪性リンパ腫に扣いて X 線診断上, 光島 ら゙)は, 溝状びらんに囲まれた粗大顆粒像“cobble stone appearance”を特徵としている.しかし本症例に おいては, 粗大顆粒像や溝状びらんなどの所見はなく, 演場と潰瘍旅痕扰よびその周囲の軽度の胃小区の不整 を認めるのみであった。 このような所見を呈したのは 病理学的に腫湟が濾胞型でなく、びまん型であったた めに結節状增殖を示さず顆粒状の変化が起こらなかっ たためと思われる，また病変が筋層や浆膜下に及んで いるにもかかわらず早期例として扱われたことについ

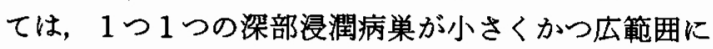
散在性に存在していたためと思われた。

病理学的には, 非ホジキン, びまん型, B cell, 中細 胞型と診断され, 免疫組織学的には一部のリンパ腫細 胞がIgG, $x, \lambda$ に染まり多クローン性バターンを示し た。一般に悪性リンパ腫は単クローン性增殖を示すと されているので, これらの多クローン性の染色パター ンは, 非特異的反応もしくは反応性の幼若リンパ球が 染色されたものと考えるのが現時点では妥当と思われ る. しかし，多クローン性を呈した悪性リンパ腫9 (1) や単クローン性を呈したRLH の報告 ${ }^{12)}$ みられるこ とから，それらの可能性も否定できない，いずれにせ よ, RLH から悪性リンパ腫への移行についての問題 ${ }^{13)}$ や免疫グロブリン染色と予後との関係10) とも合わせ て, 今後, 究明されて行かねばならない点と思われる.

治療は一般に胃切除とリンパ節郭清が行われるが, 本症例のように, びまん性の浸潤を示するのでは切除 範团の決定が困難であり術中迅速病理診断でも診断不 可能のことがある. 今後, 術中迅速醭素抗体法などの
手法を用いるべきかと思われる。また予後については， 表層払大型では非常に良好な経過をとるとされ，高木 らの報告 ${ }^{3}$ によると早期・リンバ節転移陰性例で 5 年 生存率 $90 \%$ ，リンパ節転移陽性例でも $75 \%$ とされてい る.しかし，本症例では肉眼所見が軽微であるにもか かわらず著しいリンパ節転移を呈し短期間のらちに全 身転移を起こして死亡したことより，非常に特異な症 例とい亲るが，胃悪性リンパ腫の詥断・治療において， このような症例が存在することを常に念頭に颃いて慎 重に対処すべきだと思われる。

\section{IV. 結 語}

軽微な肉眼所資にもかかわらず著しい浸潤転移をき たした原発性胃悪性リンパ腫について，若干の文献的 考察を加えて報告した。

\section{文 献}

1）佐野量造：胃疾患の臨床病理. 医学畫院, 東京, 1979, p257-274

2) 大井 実, 三穂乙実, 伊東 保棌：非癌性胃畽 陽. 外科 $29: 112-133,1967$

3）高木敏之，小黒昌夫, 馬場 尚浪：胃癌原発生悪 性リンバ腫。癌の臨 $26: 353-360,1980$

4）崎田隆夫, 福富久之：新内科学大系, 第17巻 A, 中 山書店, 東京, 1978, p208-218

5）中沢三郎，川口新平, 芳野純治ほか：胃悪性リンパ 腫の X 線診断。消外 $7: 1142-1457,1984$

6）八尾恒良, 中沢三郎, 中村恭一ほか：胃悪性リンパ 腫の集計成積。胃と腸 $15: 906-908,1980$

7）森 茂郎：消化管の悪性リンバ腫. 病理と臨 4 ： 480-485, 1986

8）光島徹, 吉田茂昭, 岡 裕爾ほか：胃悪性リンパ 腫の早期診断指標. Prog Dig Endosc $16: 97$ $-101,1980$

9) Saraga P, Hurliman J, Ossello L: Lymphoma and pseudolymphoma of the alimentary tract. Hum Pathol 12:713-723, 1981

10）中村敬夫：胃腸管悪性リンパ腫の臨床病理学的並 びに免疫組織学的検討。日消病会誌 $79: 2216$ $-2226,1982$

11) Pavlova Z, Parker JW, Taylor $\mathrm{CR}$ et al: Small noncleaved follicular center cell lymphoma. Cancer 59 : 1892-1902, 1987

12) Eimoto T, Futami $K$, Naito $H$ et al: Gastric pseudolymphoma with monotypic cytoplasmic immunogloburin. Cancer $55:$ 788-793, 1985

13) Scoazec J-Y, Brousse N, Potet F et al: Focal malignant lymphoma in gastric pseudolymphoma. Cancer $57: 1330-1336,1986$ 